\title{
Aminophylline and increased activity of peripheral chemoreceptors in newborn infants
}

\author{
Luigi Cattarossi, Stefania Rubini, Franco Macagno
}

\begin{abstract}
Peripheral chemoreceptor activity was studied in nine healthy, unsedated neonates (with a mean (SD) postconceptional age of 39 (2) weeks and birth weight of 3000 (400) $\mathrm{g}$ ) by measuring the inhibition of ventilation elicited by five breaths of $100 \%$ oxygen (Dejours technique). Changes in tidal volume, frequency, and minute ventilation were measured before and after administration of aminophylline $(10 \mathrm{mg} / \mathrm{kg}$ by mouth). Before aminophylline hyperoxia induced a decrease in minute ventilation (from a mean (SE) of 825 (55) to 520 (30) $\mathrm{m} / \mathrm{kg} / \mathrm{min}$ ) as result of reduction of tidal volume (from $12(0.3)$ to $8(0.3) \mathrm{ml}$ kg). After aminophylline administration the hyperoxia induced decrease in tidal volume (from $14(0.7)$ to $6(0.3) \mathrm{m} / \mathrm{kg}$ ) and minute ventilation (from 847 (57) to 386 (21) $\mathrm{m} / \mathrm{kg} / \mathrm{min}$ ) was significantly greater than before. It is concluded that in neonates peripheral chemoreceptors are more active in the presence of aminophylline. It is speculated that aminophylline increases the activity of peripheral chemoreceptors, reducing the breakdown of CAMP, which is a crucial mediator for peripheral chemoreceptor discharge.

(Arch Dis Child 1993; 69: 52-54)
\end{abstract}

The site of action of methylxanthines on respiratory activity is thought to be the central nervous system. ${ }^{1}{ }^{2}$ It has been proposed that these drugs lower the threshold of central respiratory neurons to inputs from central chemoreceptive systems, partly antagonising the hypoxic respiratory depression related to adenosine release, ${ }^{3}$ and increasing metabolic rate and alveolar ventilation. ${ }^{4}$ In peripherally chemodenervated adult animals, aminophylline also reverses the respiratory depression due to hypoxia. ${ }^{5}$ However recently published data suggest that the action of methylxanthines may not be purely central. In lambs breathing room air administration of caffeine increases tidal volume, minute ventilation, and frequency only in the presence of intact peripheral chemoreceptors. ${ }^{6}$ In newborn piglets aminophylline failed to reverse the hypoxic depression after carotid body denervation. ${ }^{7}$ This suggests that

Accepted 25 January 1993

Table 1 Individual perinatal data

\begin{tabular}{|c|c|c|c|c|c|c|c|c|c|}
\hline & \multicolumn{9}{|c|}{ Case No } \\
\hline & 1 & 2 & 3 & 4 & 5 & 6 & 7 & 8 & 9 \\
\hline $\begin{array}{l}\text { Birth weight (g) } \\
\text { Gestational age (weeks) } \\
\text { Postnatal age (days) } \\
\text { Postconceptional age (weeks) }\end{array}$ & $\begin{array}{r}3300 \\
36 \\
7 \\
37\end{array}$ & $\begin{array}{r}2400 \\
37 \\
14 \\
39\end{array}$ & $\begin{array}{r}3200 \\
38 \\
14 \\
41\end{array}$ & $\begin{array}{r}3100 \\
40 \\
8 \\
41\end{array}$ & $\begin{array}{r}3200 \\
40 \\
9 \\
41\end{array}$ & $\begin{array}{r}2400 \\
36 \\
8 \\
37\end{array}$ & $\begin{array}{r}3500 \\
41 \\
6 \\
41\end{array}$ & $\begin{array}{r}2500 \\
36 \\
15 \\
38\end{array}$ & $\begin{array}{r}2700 \\
38 \\
8 \\
39\end{array}$ \\
\hline
\end{tabular}

peripheral chemoreceptors may play an important part in the action of methylxanthines in neonates even though carotid bodies exhibit relative inactivity after birth. Peripheral chemoreceptor activity in neonates is conventionally assessed by the immediate (in the first minute) decrease in ventilation observed during inhalation of $100 \%$ oxygen. ${ }^{8}$ If the infant continues to breathe pure oxygen a late increase in ventilation occurs. The initial decrease is thought to be determined by peripheral chemoreceptors inhibiting signals to the brainstem while the late increase is centrally mediated.

We utilised this technique to assess the activity of peripheral chemoreceptors in newborn infants before and after administration of aminophylline.

\section{Subjects and methods}

Nine healthy, unsedated newborn babies (with a mean (SD) postconceptional age of 39 (2) weeks, birth weight 3000 (400) g, and postnatal age 10 (3) days; table 1) were studied. None of the infants suffered from respiratory problems, perinatal asphyxia, or any problem that could affect their ventilatory responses. No infant was taking any medication except for vitamin supplementation.

Studies were performed on the babies in a quiet environment during sleep and after feeding; they were kept in their crib in a comfortable position. Flow was measured with a facemask (nasal, dead space $5 \mathrm{ml}$ ) attached to a neonatal Fleisch pneumotachograph. Flow was integrated to obtain volume. The mask (sealed with clay) was applied to the face only for the time necessary for recordings to be made; the mouth was kept closed during data collection.

Transcutaneous oxygen $\left(\mathrm{Po}_{2}\right)$ and carbon dioxide $\left(\mathrm{PCO}_{2}\right)$ tension and oxygen saturation were continuously recorded. An oximeter (response time 0.2 seconds) connected to the facemask was used to measure the oxygen concentration present in the mask. A blender (Mixer AO-1, Puritan Bennett) connected by a short hose (inner diameter $6 \mathrm{~mm}$ ) to the mask was used to change the oxygen concentration. A flow of $0.8 \mathrm{l} / \mathrm{min}$ (perpendicular to the pneumotachograph) was kept constant, avoiding generation of turbulence in the pneumotachograph. This constant bias flow prevented carbon dioxide accumulation in the mask. Basal measurements of tidal volume, frequency, and minute ventilation were obtained by breath to breath analysis (over one minute) utilising the PeDS system (MAS Inc).

Oxygen at $100 \%$ was then supplied to the mask and after five breaths was interrupted by switching the blender back to room air. The 
Table 2 Individual and mean (SE) changes in ventilation elicited by hyperoxia before and after aminophylline (tidal volume (ml/kg), frequency (breaths/min), minute ventilation ( $\mathrm{ml} / \mathrm{kg} / \mathrm{min}$ ) respectively)

\begin{tabular}{|c|c|c|c|c|c|c|c|c|c|c|c|c|}
\hline \multirow[b]{3}{*}{$\begin{array}{l}\text { Case } \\
\text { No }\end{array}$} & \multicolumn{6}{|c|}{ Before aminophylline } & \multicolumn{6}{|c|}{ After aminophylline } \\
\hline & \multicolumn{3}{|l|}{ Control } & \multicolumn{3}{|c|}{ After hyperoxia } & \multicolumn{3}{|l|}{ Control } & \multicolumn{3}{|c|}{ After hyperoxia } \\
\hline & $\begin{array}{l}\text { Tidal } \\
\text { volume }\end{array}$ & Frequency & $\begin{array}{l}\text { Minute } \\
\text { ventilation }\end{array}$ & $\begin{array}{l}\text { Tidal } \\
\text { volume }\end{array}$ & Frequency & $\begin{array}{l}\text { Minute } \\
\text { ventilation }\end{array}$ & $\begin{array}{l}\text { Tidal } \\
\text { volume }\end{array}$ & Frequency & $\begin{array}{l}\text { Minute } \\
\text { ventilation }\end{array}$ & $\begin{array}{l}\text { Tidal } \\
\text { volume }\end{array}$ & Frequency & $\begin{array}{l}\text { Minute } \\
\text { ventilation }\end{array}$ \\
\hline $\begin{array}{l}1 \\
2 \\
3 \\
4 \\
5 \\
6 \\
7 \\
8 \\
9\end{array}$ & $\begin{array}{c}18(2) \\
6(1) \\
8(0 \cdot 4) \\
10(1) \\
12(1) \\
11(2) \\
8(0 \cdot 4) \\
20(1) \\
12(1)\end{array}$ & $\begin{array}{l}70(2) \\
65(3) \\
60(1) \\
61(2) \\
47(3) \\
57(3) \\
70(2) \\
72(2) \\
59(3)\end{array}$ & $\begin{array}{c}1415(146) \\
437(46) \\
417(14) \\
683(116) \\
541(47) \\
671(71) \\
560(101) \\
1461(143) \\
360(12)\end{array}$ & $\begin{array}{c}13(2) \\
8(1) \\
5(0 \cdot 3) \\
6(0 \cdot 3) \\
5(0 \cdot 3) \\
8(0 \cdot 7) \\
9(1) \\
13(1) \\
7(0 \cdot 5)\end{array}$ & $\begin{array}{l}53(3) \\
74(2) \\
44(0 \cdot 3) \\
75(0 \cdot 3) \\
43(2) \\
70(2) \\
72(2) \\
68(3) \\
62(2)\end{array}$ & $\begin{array}{l}681(101) \\
597(39) \\
188(10) \\
396(11) \\
157(3) \\
560(101) \\
648(90) \\
990(95) \\
467(30)\end{array}$ & $\begin{array}{c}21(1) \\
8(0 \cdot 4) \\
14(0 \cdot 7) \\
9(0 \cdot 7) \\
13(1) \\
8(0 \cdot 7) \\
17(1) \\
24(1) \\
10(0 \cdot 7)\end{array}$ & $\begin{array}{l}80(2) \\
75(3) \\
44(1) \\
68(4) \\
29(3) \\
50(2) \\
82(3) \\
60(3) \\
45(1)\end{array}$ & $\begin{array}{c}1626(56) \\
497(42) \\
606(22) \\
625(77) \\
380(43) \\
384(36) \\
1543(140) \\
1498(124) \\
459(31)\end{array}$ & $\begin{array}{c}9(1) \\
4(0 \cdot 1) \\
5(0 \cdot 7) \\
4(0 \cdot 3) \\
6(0 \cdot 7) \\
4(1) \\
7(1) \\
10(1) \\
6(1)\end{array}$ & $\begin{array}{l}80(1) \\
74(8) \\
41(5) \\
76(1) \\
32(2) \\
40(1) \\
57(2) \\
60(3) \\
67(4)\end{array}$ & $\begin{array}{l}748(70) \\
296(28) \\
217(49) \\
307(9) \\
117(12) \\
197(28) \\
501(45) \\
629(56) \\
363(9)\end{array}$ \\
\hline Mean (SE) & $12(0.3)$ & $71(2)$ & $825(55)$ & $8(0.3)^{\star}$ & $61(2)$ & $520(30)$ & $14(0 \cdot 7)$ & $59(2)$ & $847(57)$ & $6(0 \cdot 3) \dagger$ & $60(2)$ & $386(21) \ddagger$ \\
\hline
\end{tabular}

${ }^{\star} \mathrm{p}<0.01 v$ control; $\uparrow \mathrm{p}<0.05 v$ control; $\mathrm{f} p<0.001 v$ control; $\ddagger \mathrm{p}<0.01 v$ control (one way analysis of variance).

Table $3 \mathrm{FIO}_{2}$, oxygen saturation, and blood gas assessment before aminophylline. Values are mean (SD)

\begin{tabular}{lccc}
\hline & Control & $\begin{array}{l}\text { After } \\
\text { hyperoxia }\end{array}$ & $p$ Value \\
\hline Fro $_{2}$ & 0.21 & $0.59(0.04)$ & $<0.001$ \\
Oxygen saturation $(\%)_{\text {Transcutaneous } \mathrm{Po}_{2}(\mathrm{kPa})}$ & $94(0.9)$ & $95(2)$ & $\mathrm{NS}$ \\
Transcutaneous $\mathrm{PCO}_{2}(\mathrm{kPa})$ & $7.86(0.67)$ & $7.86(0.67)$ & $\mathrm{NS}$ \\
& $4.93(0.40)$ & $5.07(0.27)$ & $\mathrm{NS}$ \\
\hline
\end{tabular}

Table $4 \mathrm{FIO}_{2}$, oxygen saturation, and blood gas assessment after aminophylline. Values are mean (SD)

\begin{tabular}{lccc}
\hline & Control & $\begin{array}{l}\text { After } \\
\text { hyperoxia }\end{array}$ & p Value \\
\hline $\mathrm{FrO}_{2}$ & 0.21 & $0.61(0.04)$ & $<0.001$ \\
Oxygen saturation $(\%)_{\text {Transcutaneous } \mathrm{PO}_{2}(\mathrm{kPa})}$ & $94(0.8)$ & $95(1.5)$ & $\mathrm{NS}$ \\
Transcutaneous $\mathrm{PCO}_{2}(\mathrm{kPa})$ & $7.86(0.93)$ & $7.73(0.93)$ & $\mathrm{NS}$ \\
& $5.47(0.13)$ & $5.47(0.40)$ & NS \\
\hline
\end{tabular}

next 10 breaths were again analysed by breath to breath analysis to assess the influence of peripheral chemoreceptor activity on tidal volume, frequency, and minute ventilation. The sequence was repeated three times for each baby and the data obtained averaged. The entire protocol was repeated the same day one hour after administration of a loading dose of aminophylline (10 $\mathrm{mg} / \mathrm{kg}$ by mouth).

Data were analysed using the paired $t$ test, and one way and two way analysis of variance for repeated measures. For the comparison of the magnitude of change before and after administration of aminophylline the absolute values were converted to percentage of maximum. The highest absolute value obtained for each variable studied was considered to be the maximum, the variation from this maximum absolute value has been expressed as its percentage. All data are expressed as mean (SE) unless otherwise indicated.

After approval of the protocol by the hospital ethical committee informed consent was obtained from the parents.

\section{Results}

RESPONSE TO HYPEROXIC BREATHS BEFORE AMINOPHYLLINE

Inhalation of pure oxygen induced a decrease of ventilation in all but two of the infants studied (numbers 2 and 9, table 2). The mean minute ventilation dropped from 825 (55) to $520(30) \mathrm{ml} / \mathrm{kg} / \mathrm{min}(\mathrm{p}<0.05)$ as a result of reduction of tidal volume from $12(0.3)$ to 8
$(0.3) \mathrm{ml} / \mathrm{kg}(\mathrm{p}<0.01)$; the frequency did not change (table 2 ).

The fraction of inspired oxygen $\left(\mathrm{FIO}_{2}\right)$ that was reached in the mask during the five hyperoxic breaths was mean (SD) $0.59(0.04)$. Transcutaneous $\mathrm{PO}_{2}$ and $\mathrm{PCO}_{2}$ and oxygen saturation did not change significantly (table 3 ).

\section{RESPONSE TO HYPEROXIC BREATHS AFTER} AMINOPHYLLINE

All infants studied showed a decrease of ventilation after inhalation of pure oxygen. Minute ventilation decreased from 847 (57) to 386 (21) $\mathrm{ml} / \mathrm{kg} / \mathrm{min}(\mathrm{p}<0.01)$ due to tidal volume reduction from $14(0.7)$ to $6(0.3) \mathrm{ml} / \mathrm{kg}$ $(\mathrm{p}<0.001)$; the frequency was unchanged (table 2). The mean (SD) $\mathrm{FIO}_{2}$ reached in the mask was $0.61(0.04)$ compared with 0.59 $(0.04)$ before aminophylline $(p=0 \cdot 1)$. Basal tidal volume increased after the loading of aminophylline $(12(0.3)$ v $14(0.7) \mathrm{ml} / \mathrm{kg}$, $\mathrm{p}<0.05)$. Blood samples taken at the end of the study showed a mean (SD) aminophylline blood concentration of $0.9(0.1) \mathrm{mg} / 100 \mathrm{ml}$. Transcutaneous blood gases and oxygen saturation did not change (table 4).

COMPARISON OF THE RESPONSE TO HYPEROXIA BEFORE AND AFTER AMINOPHYLLINE

Table 5 shows the changes in ventilation elicited by inhalation of pure oxygen before and after aminophylline. The drop in minute ventilation and tidal volume was significantly greater after aminophylline (both $\mathrm{p}<0 \cdot 05$, two way analysis of variance). Before aminophylline both the minute ventilation and tidal volume decreased: from $96(2)$ to $65(8) \%$ and

Table 5 Comparison of hyperoxia induced changes in ventilation before and after aminophylline. Values are $\%$ of maximum ( $S E$ )

\begin{tabular}{|c|c|c|c|}
\hline & Control & $\begin{array}{l}\text { After } \\
\text { hyperoxia }\end{array}$ & $p$ Value ${ }^{\star}$ \\
\hline \multicolumn{4}{|c|}{ Tidal volume } \\
\hline $\begin{array}{l}\text { Before } \\
\text { After }\end{array}$ & $\begin{array}{r}97(2) \\
100\end{array}$ & $\begin{array}{l}70(6) \\
46(2)\end{array}$ & $<0.05$ \\
\hline \multicolumn{4}{|c|}{ Frequency } \\
\hline $\begin{array}{l}\text { Before } \\
\text { After }\end{array}$ & $\begin{array}{l}96(2) \\
92(3)\end{array}$ & $\begin{array}{l}85(5) \\
93(3)\end{array}$ & NS \\
\hline \multicolumn{4}{|c|}{ Minute ventilation } \\
\hline $\begin{array}{l}\text { Before } \\
\text { After }\end{array}$ & $\begin{array}{c}96(2) \\
100\end{array}$ & $\begin{array}{l}65(8) \\
49(4)\end{array}$ & $<0.05$ \\
\hline
\end{tabular}

$\star$ Two way analysis of variance before $v$ after aminophylline. 
from 97 (2) to $70(6) \%$ of maximum activity, respectively, while after aminophylline the minute ventilation dropped from 100 to 49 (4) $\%$ and the tidal volume from 100 to 46 (2) $\%$; the frequency was not affected.

\section{Discussion}

The single breath of $100 \%$ oxygen was introduced by Dejours et al to quantify the influence of peripheral chemoreceptors on ventilation. ${ }^{8}$ Girard et al first applied this method in neonates. ${ }^{9}$ We utilised a modified version of the method with a relatively longer exposure to oxygen (five breaths) as proposed by Hertzberg and Lagercrantz. ${ }^{10}$ In neonates the possibility exists of venous and arterial blood mixing because of shunts and subsequent insufficient rise in oxygen tension to stimulate peripheral chemoreceptors. ${ }^{11}$ Moreover our method fulfilled the requirements that suggest an exposure to oxygen short enough not to affect the central respiratory structures with an increased $\mathrm{PCO}_{2}$ caused by diminished ventilation. This is confirmed by the values of the transcutaneous $\mathrm{PCO}_{2}$ that did not change after hyperoxia both before and after aminophylline administration (tables 3 and 4). Because of the low flow supplied to the mask, the exposure to oxygen, and the possible mixture with room air through the open port of the pneumotachograph a $\mathrm{FIO}_{2}$ of less than $1(0.59$ to 0.61$)$ was reached. However this $\mathrm{FIO}_{2}$ was constant during the five breaths and the levels reached elicited a good respiratory response. Two of the subjects studied (numbers 2 and 9, table 2) did not show a decrease in ventilation in response to hyperoxia before aminophylline. One of the infants had a gestational age of 37 weeks but the second had a gestational age of 41 weeks, and both of them were over 38 weeks' postconceptional age at the time of the measurements. Therefore we believe that this lack of response can be attributed to individual variation of chemoreceptor sensitivity rather than to their relative immaturity. This study indicates that in the presence of aminophylline the activity of peripheral chemoreceptors in term newborn infants is enhanced.

In this group of term infants the reduction in minute ventilation, either before or after aminophylline, was the result of a drop in tidal volume while the frequency did not change. This is in agreement with the findings of Aizad et al. ${ }^{12}$

Our results confirm previous studies in animal models, which have indicated that peripheral chemoreceptors are crucial for methylxanthines to exert fully their stimulant activity on respiration. ${ }^{67}$ Unfortunately the mechanism of action through which methylxanthines act on peripheral chemoreceptors is unknown. It cannot be the antagonistic activity of aminophylline toward adenosine because it is well known that adenosine administered systemically increases respiratory activity. ${ }^{13}$ Moreover consistent amounts of adenosine have been found in the carotid bodies during hypoxia, when they are extremely active, as well as other mediators with whom aminophylline can interfere. ${ }^{14}$

The inhibiting activity of aminophylline on phosphodiesterase can also be involved in the action of peripheral chemoreceptors. cAMP is an important mediator for carotid body discharge. ${ }^{15}$ Aminophylline may enhance the activity of carotid bodies reducing the breakdown metabolism of cAMP by inhibition of phosphodiesterase. From a clinical point of view the interpretation of our results is quite difficult. At the present time the role of peripheral chemoreceptors in neonates is still controversial. Hertzberg and Lagercrantz, ${ }^{10}$ Bureau et $a l,{ }^{16}$ and Eden and Hanson ${ }^{17}$ suggest a maturation of peripheral chemoreceptors from fetal to extrauterine life, but Aizad et al found more active peripheral chemoreceptors in preterm infants compared with term infants. Therefore if it would be easy to say, according to our data, that the efficacy of aminophylline in the treatment of apnoea of prematurity depends also on its activity on peripheral chemoreceptors, which are relatively immature in preterm infants; this is in clear contrast to other findings. ${ }^{12}$

In conclusion, even though the action of methylxanthines on peripheral chemoreceptors seems to be proved, further studies are needed to understand fully the biochemical basis of their activity. It is still unclear whether aminophylline acts similarly on apnoea of prematurity through stimulation of peripheral chemoreceptors.

1 LeMessurier DH. The site of action of caffeine as respiratory stimulant. $\mathcal{F}$ Pharmacol Exp Ther 1936; 57: 458-70. 2 Aranda JV, Turmen T. Methylxanthines in apnea of prematurity. Pediatr Clin North Am 1981; 28: 113-33.

3 Darnall RA. Aminophylline reduces hypoxic ventilatory depression: possible role of adenosine. Pediatr Res 1985; 13: $706-10$.

4 Cote A, Blanchard PW, Meehan B. Metabolic and cardiorespiratory effects of doxapram and theophylline in diorespiratory effects of doxapram and theophylline in 4leeping

5 Javaheri S, Teppema LJ. Effects of aminophylline on hypoxia induced ventilatory depression in the cat. $\mathcal{F} A p p l$ Physiol 1988; 64: 1837-43.

6 Blanchard PW, Cote A, Hobbs S, Foulon P, Aranda JV, Bureau MA. Abolition of ventilatory response to caffeine in chemodenervated lambs. F Physiol 1986; 61: 133-7.

7 Cattarossi L, Haxhiu-Poskurica B, Haxhiu MA, Litmanovitz I, Martin RJ, Carlo WA. Peripheral chemoreceptors determine the ventilatory response to aminophylline in hypoxic newborn piglets. Am Rev Respir Dis 1991; 143: A189.

8 Dejours P, Larousse Y, Raynaud J, Girard F, Teillac A. Stimulus oxygene de la ventilation au repos et au cours de l'exercise muscolare a basse altitude $(50 \mathrm{~m})$ chez l'homme. Revue Française d'Etudes Cliniques et Biologiques 1958; 3: 105-23.

9 Girard F, Lacaisse A, Dejours P. Le stimulus O2 ventilatoire a la periode neonatale chez l'homme. I Physiol (Paris) 1960; 52: 108-9.

10 Hertzberg $T$, Lagercrantz $H$. Postnatal sensitivity of the peripheral chemoreceptors in newborn infants. Arch Dis Child 1987; 62: 1238-41.

11 Purves MJ. The effect of single breath of oxygen on respiration in the newborn lamb. Respir Physiol 1966; 1: tion in $297-307$.

12 Aizad T, Bodani J, Cates D, Horvath L, Rigatto H. Effect of single breath of $100 \%$ oxygen on respiration in neonates single breath of $100 \%$ oxygen on respiration in
during sleep. $F$ Appl Physiol 1984; 57: 1531-5.

13 Eyzaguirre C, Zapata P. Perspectives in carotid body research. $\mathcal{f}$ Appl Physiol 1984; 57: 931-57.

14 Lundberg JM, Holfelt T, Fahrenkrug J, Nilsson CT, Terenius L. Peptides in the cat carotid body (glomus caroticum): VIP-, enkephalin- and substance P- like immunoreactivity. Acta Physiol Scand 1979; 107: 279-81.

15 Wang WJ, Cheng GF, Dinger BG, Fidone SG. Effects of hypoxia on cyclic nucleotide formation in rabbit carotid body in vitro. Neurosci Lett 1989; 105: 164-8.

16 Bureau MA, Lamarche J, Foulon P, Dalle D. The ventilatory response to hypoxia in the newborn lamb after carotid body denervation. Respir Physiol 1985; 60: 109-19.

17 Eden GJ, Hanson MA. The effect of hypoxia from birth on the biphasic respiratory response of the newborn rat to acute hypoxia. F Physiol 1985; 366: 59P. 